\title{
ARTIKELEN
}

\section{De herziening van de Wet op de orgaandonatie: een terugblik}

\author{
Prof. mr. J.K.M. Gevers*
}

Het is dan uiteindelijk toch gebeurd: na jarenlange discussie over het bestaande beslissysteem voor postmortale orgaandonatie, is dat onlangs gewijzigd. Het daartoe strekkend initiatiefwetsvoorstel van D66 Tweede Kamerlid Pia Dijkstra ${ }^{1}$ is door beide Kamers aanvaard, zij het met de kleinst mogelijke meerderheid. In de Tweede Kamer gebeurde dat al op 13 september 2016 (met 75 stemmen voor en 74 tegen), in de Eerste Kamer op 13 februari 2018 (38 voor, 36 tegen). Even leek het erop dat er nog een spaak in het wiel zou komen. $\mathrm{Na}$ publicatie van de wetswijziging in het Staatsblad op 27 maart $2018^{2}$ is er een burgerinitiatief gestart voor een raadgevend referendum over de wetswijziging. Op de sluitingsdatum 14 juni bleek het initiatief echter onvoldoende handtekeningen te hebben gekregen, waardoor het van de baan was.

Dat de wet is aangenomen betekent echter nog lang niet dat hij is ingevoerd. De voorbereiding daarvan vergt meerdere tijdrovende implementatiestappen. De belangrijkste daarvan is een intensief voorlichtingstraject over het nieuwe Actief Donorregistratiesysteem (ADR); daarnaast gaat het onder meer om aanpassing van het Donorregister en de ontwikkeling van een kwaliteitsstandaard betreffende de rolverdeling tussen hulpverlener en nabestaanden (ter borging van de positie van laatstgenoemden). De beoogde datum van inwerkingtreding is nu 1 juli 2020.

Doel van deze bijdrage is terug te blikken op de totstandkoming van de wet en bij het eindresultaat vanuit juridisch perspectief een aantal kanttekeningen te plaatsen. Daartoe begin $\mathrm{ik}$ met het meer in context plaatsen van de discussie over het beslissysteem. Dan volgt een samenvatting van wat de nieuwe regels inhouden. In het beschouwende deel ga ik eerst in op de grond- en mensenrechtelijke aspecten die bij de totstandkoming (en de discussie daarom heen) veel aandacht hebben gekregen. Daarna komen achtereenvolgens aan de orde: de positie van nabestaanden (waarover de initiatiefneemster tot op het laatst toe in de Eerste Kamer het vuur aan de schenen is gelegd), en vervolgens twee punten waarvoor veel minder aandacht is geweest, te weten de regels rond wilsonbekwaamheid en die ten aanzien van voorbereidende handelingen. Vooral dat laatste punt is nogal verwaarloosd, hoewel het samenhangt met het beslissysteem en niet zonder betekenis is voor de wijze waarop dat te waarderen is.

* Sjef Gevers is emeritus-hoogleraar gezondheidsrecht, AMC/UVA.

1 Voorstel tot wijziging van de Wet op de orgaandonatie in verband met het opnemen van een actief donorregistratiesysteem, Kamerstukken II 2013/14, 33506, 1-3.

2 Stb. 2018, 95. 


\section{De Wet op de orgaandonatie en het beslissysteem}

Het huidige beslissysteem is bij totstandkoming van de WOD geïntroduceerd als een zogenoemd 'volledig beslissysteem', d.w.z. dat de burger zowel bezwaar als toestemming kan laten registreren. In feite gaat het echter om de toestemming: die is nodig voor orgaanuitname. Ontbreekt die, dan kan - tenzij bezwaar is aangetekend - alleen nog tot uitname worden overgegaan als de nabestaanden of een specifiek door de donor aangewezen persoon daarmee instemmen. Vanwege dat laatste aspect werd het beslissysteem van de WOD ook wel aangeduid als een 'onzuiver toestemmingssysteem'. Dat in de WOD oorspronkelijk voor dat systeem gekozen is, heeft onder meer te maken met het draagvlak daarvoor onder de bevolking, het feit dat men alles afwegend een geen-bezwaarsysteem toch een te grote inbreuk op de individuele autonomie achtte, en het feit dat in landen met een dergelijk systeem niet altijd sprake was van een duidelijk groter aanbod van organen. Ook toen was er echter al veel discussie over die systeemkeuze.

Ook in de ruim twintig jaar na totstandkoming van de wet heeft het beslissysteem in samenleving, media en politiek veel aandacht gekregen. ${ }^{3}$ Dat is niet onbegrijpelijk: het gaat in beginsel elke burger aan, het raakt de intieme persoonlijke levenssfeer, en er zijn principiële ethische en juridische vragen bij in het geding. Tegelijk betreft het echter slechts een onderdeel van de wet. Die regelt ook het afstaan van organen bij leven, een vorm van donatie die in de loop der jaren steeds belangrijker is geworden. Maar ook als men alleen naar postmortale orgaandonatie kijkt, is het beslissysteem niet het enige aspect daarvan en zeker ook niet het enige waarover discussie mogelijk is. Men denke bijvoorbeeld aan het vaststellen van de dood, de verdeling van beschikbare organen, en handelingen ter voorbereiding van orgaanverwijdering; allemaal zaken die óók in de wet geregeld worden.

Niettemin is het bij de discussies over de WOD voornamelijk om het beslissysteem gegaan. ${ }^{4}$ Werd in de eerste evaluatie van de WOD (2001) nog geconstateerd dat concluderende uitspraken over het gekozen beslissysteem nog niet mogelijk waren, in de tweede evaluatie van de wet $(2004)^{5}$ stond al de vraag centraal of een wijziging van het beslissysteem zou bijdragen aan toename van het aantal postmortale organen. De conclusie was echter dat de overgang naar een geen-bezwaarsysteem vermoedelijk te weinig extra donoren zou opleveren om zo'n ingrijpende wijziging te rechtvaardigen, temeer om dat er ook nog andere opties waren om het aanbod aan organen te vergroten. Het kabinet sloot zich daarbij aan.

Verdere mijlpalen in de discussie over het beslissysteem:

- In 2004 komt het Nationaal Instituut voor Gezondheidsbevordering en Ziektepreventie met een variant op het inmiddels in de WOD neergelegde ADR-systeem (zie over

3 Zo ook in de literatuur; zie bijvoorbeeld J.G. Sijmons, 'Beschikken over organen na overlijden: organen als collectieve nalatenschap?', Ned. T. v. Burgerlijk Recht 2013, nr. 7.

4 De belangrijkste uitzondering daarop is misschien wel de discussie over het wel of niet introduceren van enigerlei vorm van wederkerigheid bij de verwerving en toedeling van organen, waarover vooral in de jaren 2003 en 2004 het nodige te doen is geweest (in de eenvoudigste variant: wie zelf geen donor wil zijn komt ook niet in aanmerking een orgaan te ontvangen). Zie daarover o.a. G. den Hartogh, Gift of bijdrage? Over morele aspecten van orgaandonatie, Den Haag: Rathenau Instituut 2003, en R.D. Friele e.a., Derde evaluatie Wet op de orgaandonatie, Den Haag: ZonMw 2006, p. 115-135.

5 Tweede evaluatie Wet op de orgaandonatie, Den Haag: ZonMw 2004. 
dat systeem verder hierna). Na onderzoek door het NIVEL concludeerde het kabinet dat de invoering van het voorgestelde systeem nog een aantal vragen opriep, dat de voordelen ervan (in termen van meer donoren) nog onzeker waren, en dat het alles afwegend beter was om vooralsnog van invoering af te zien. ${ }^{6}$

- De derde evaluatie van de WOD (2006) richtte zich onder meer op de effecten van andere beleidsinitiatieven om het aanbod van organen te vergroten (zoals voorlichtingscampagnes en verbetering van beleid en procedures in ziekenhuizen). Die initiatieven leken vruchten af te werpen: het aantal donoren groeide. Het tekort aan organen bleef echter zodanig dat de mogelijkheid van een systeemwijziging toch op de agenda bleef staan. ${ }^{7}$

- In 2008 brengt de Coördinatiegroep orgaandonatie het Masterplan Orgaandonatie ${ }^{8}$ uit. Daarin adviseren de meeste veldpartijen om een ADR-systeem in te voeren. Opnieuw reageert het kabinet terughoudend: afgezien van het feit dat zo'n systeem de kans zou vergroten dat niet conform de wens van de donor wordt gehandeld, zouden de effecten van een verandering onvoldoende vaststaan.

- Vervolgens liet de minister van VWS onderzoek uitvoeren door de Universiteit Tilburg naar de verschillende voorstellen om de toename van het aantal donoren te bevorderen. Ook dat leverde geen eenduidig antwoord op. Dat bracht het kabinet in 2011 tot de conclusie dat een (verdere) inbreuk op het zelfbeschikkingsrecht alleen te rechtvaardigen zou zijn bij een aanzienlijke toename van het aantal donoren, maar dat de effecten van een systeemwijziging nog steeds te onzeker waren om daartoe over te gaan. $^{9}$

Kortom, aan aandacht voor de mogelijke merites van een ander beslissysteem heeft het al die tijd niet ontbroken. Maar tot aan het initiatiefvoorstel van D66 heeft dat niet tot aanpassing van de WOD geleid.

\section{Het nieuwe beslissysteem in de WOD}

Het nieuwe beslissysteem sluit aan bij een van de hoofddoelstellingen van de wet: verhoging van het aanbod aan postmortale organen. Dat aanbod is in ons land relatief laag; jaarlijks overlijden er patiënten op de wachtlijst omdat geen orgaan voor hen beschikbaar is. Volgens de memorie van toelichting bij het initiatiefvoorstel ${ }^{10}$ was wijziging van het beslissysteem - naast andere maatregelen - noodzakelijk om hier verandering in te brengen. Conform het advies in het Masterplan Orgaandonatie zou het onzuivere toestemmingssysteem moeten worden vervangen door een ADR-systeem. De keuze daarvoor hangt samen met het gegeven dat op dat moment 60\% van de bevolking geen keuze met betrekking tot orgaandonatie had laten registreren. Als dan vervolgens de donatievraag aan de nabestaanden gesteld werd, was in 7 van de 10 gevallen sprake van een weigering. In de praktijk was dus veel eerder van een 'nabestaandensysteem' sprake dan van een 'volledig beslissysteem'

$6 \quad$ Kamerstukken II 2004/05, 28140,18 en 20.

$7 \quad$ Kamerstukken II 2007/08, 28140, 43.

8 'Masterplan orgaandonatie; de vrijblijvendheid voorbij', bijlage bij Kamerstukken II 2007/08, 28140, 48.

9 Kamerstukken II 2010/11, 28140, 77.

10 Kamerstukken II 2012/13, 33506, 3, p. 2-7. 
(zoals het onzuivere toestemmingssysteem van de WOD aanvankelijk was gepresenteerd). Volgens de indienster van het wetsvoorstel waren er blijkens verschillende onderzoeken goede gronden om aan te nemen dat het aantal registraties, en daarmee het aantal potentiele donoren, door invoering van een ADR-systeem aanzienlijk zou kunnen toenemen.

Het nieuwe ADR-systeem beoogt te realiseren dan van iedere Nederlandse ingezetene bekend is wat zijn of haar keuze is uit de vier opties met betrekking tot donorschap (d.w.z. toestemming geven, bezwaar maken, dan wel de nabestaanden of een specifieke persoon laten beslissen). Ook in dat systeem is registratie niet verplicht, maar wel wordt vanaf het $18 \mathrm{e}$ levensjaar iedere ingezetene aangeschreven met een donorformulier. Indien men niet reageert op dit formulier, ontvangt men binnen zes weken een herinnering. Indien men in de zes weken na het verzenden van de herinnering opnieuw niet reageert, wordt men geregistreerd als persoon die geen bezwaar heeft tegen verwijdering van organen na overlijden. De betrokkene ontvangt hiervan een bevestiging. Het is te allen tijde mogelijk de registratie te wijzigen.

Ook het nieuwe systeem gaat nog steeds uit van het zelfbeschikkingsrecht. De verandering bestaat daarin dat van ieder vanaf het 18e levensjaar wordt verwacht dat hij of zij actief invulling geeft aan dat recht, door een keuze te maken uit de vier opties in het donorformulier. In de toelichtende stukken en in een aantal bijdragen in de literatuur wordt benadrukt dat het niet gaat om een beperking van de keuzevrijheid, maar om een wijziging van de 'default' of standaardinstelling van het systeem, dat wil zeggen wat er gebeurt als men geen keuze maakt. ${ }^{11}$ Volgens de huidige wet is de beslissing dan aan de nabestaanden, volgens de nieuwe wetsbepalingen wordt men dan in principe als donor beschouwd op grond van de registratie 'geen bezwaar' die het automatisch resultaat is van niet kiezen. Alleen als er om een of andere reden helemaal niets over iemand geregistreerd is, is het woord net als voorheen aan de nabestaanden (art. 11 lid 4 WOD).

Het nieuwe regime kan niet meer beschouwd worden als een toestemmingssysteem. Toestemming is niet meer in alle gevallen vereist: organen mogen ook worden uitgenomen op basis van het feit dat de betrokkene volgens de registratie geen bezwaar heeft. Het ligt eerder tegen een geen-bezwaarsysteem aan. Hoewel men niet zonder meer donor is op grond van het enkele feit dat men geen bezwaar heeft aangetekend (men wordt verschillende malen benaderd), heeft het nieuwe regime duidelijke trekken van zo'n 'opt-out'-systeem: wie zwijgt (of liever: blijft zwijgen), stemt impliciet toe. Gelet op dat laatste kan men zich overigens afvragen of in het nieuwe systeem nog wel altijd sprake is van het ter beschikking stellen van organen' zoals de wetstitel nog steeds luidt; dat veronderstelt immers een actief element. Zie ook de in de literatuur opgeworpen vraag, of men onder het nieuwe regime nog wel van 'donatie' kan spreken. ${ }^{12}$ In een aantal gevallen zal immers geen sprake meer zijn van 'geven' maar veeleer van 'laten nemen'. Niettemin blijft in de ogen van de

11 Zie bijv. G. den Hartogh, 'Het ADR-systeem voor orgaanverwerving en de onaantastbaarheid van het lichaam', NJB 2017, nr. 43. In de Nadere MvA aan de Eerste Kamer zegt initiatiefneemster over die keuzevrijheid: "Het is weliswaar de overheid die de zogenaamde "default" heeft gekozen, maar het is aan iemand zelf om daarmee in te stemmen', Kamerstukken I 2017/18, 33506, L, p. 7-8.

12 E. Kompanje, 'Automatische donorregistratie: een ultieme poging om meer witte raven te vangen?', ZIP 2017 , jaargang 4, nr. 1 . 
initiatiefneemster sprake van 'een gift uit vrije wil', ook zonder dat sprake is van een morele verplichting om bij te dragen aan vermindering van het tekort aan organen. ${ }^{13}$

Bij dit alles is het natuurlijk ook belangrijk wat de rol van de nabestaanden is. Zij kunnen immers in belangrijke mate bepalen hoe een systeem (of dat nu als 'opt-in' of 'opt-out' te karakteriseren is) in de praktijk uitpakt. Het is daarom niet vreemd dat die rol tot in de laatste fase van de parlementaire behandeling onderwerp is geweest van veel discussie. Het gaat dan om de situatie dat iemand geregistreerd staat als een persoon die toestemming heeft verleend dan wel geen bezwaar heeft. In de wijziging van de WOD wordt hun rol volgens de wettekst (art. 20 lid 5 nieuw) aanzienlijk teruggedrongen: de wetgever wil niet alleen registratie bevorderen, maar die ook vervolgens meer bepalend laten zijn voor het al dan niet uitnemen van organen. Volgens genoemd artikellid moeten nabestaanden 'aannemelijk maken dat die registratie niet overeenkomt met de wens van de betrokkene'. Alleen in dat geval 'geldt de informatie van de nabestaanden', dat wil zeggen dat ondanks de registratie toch geen orgaandonatie kan plaatsvinden. Hieronder zal overigens blijken dat een en ander vooral als gevolg van toezeggingen aan de Eerste Kamer in de praktijk niet naar de letter, maar ruimer zal worden toegepast.

Met het bovenstaande heb ik het belangrijkste onderdeel van de wetswijziging in hoofdlijnen geschetst. Andere onderdelen van belang betreffen het beslissysteem inzake postmortale orgaanverwijdering bij wilsonbekwaamheid en de relatie van het nieuwe beslissysteem met de regels over handelingen ter voorbereiding van orgaanverwijdering bij (verwacht) overlijden. Om herhaling te voorkomen kom ik op de desbetreffende nieuwe regels later in de navolgende paragraaf terug.

\section{Beschouwing}

\subsection{Grond- en mensenrechtelijke aspecten}

Discussies over het beslissysteem spitsen zich al snel toe op de vraag of een geen-bezwaarsysteem of een systeem dat daar dicht tegenaan ligt (zoals het nieuwe ADR-systeem), zich wel verdraagt met grond- en mensenrechten, en in het bijzonder de integriteit van het menselijk lichaam. De inbreuk die orgaanuitname daarop potentieel maakt, wordt immers in dat geval niet meer gelegitimeerd door toestemming van de betrokkene.

Vanuit het Europese mensenrecht bezien is de kwestie weinig problematisch. In Europa heeft een meerderheid van landen een geen-bezwaarsysteem. Er zijn geen uitspraken van het Hof voor de Rechten van de Mens in Straatsburg waarin dat in strijd met mensenrechten, zoals het recht op privéleven (art. 8 EVRM), is bevonden. Aan de lidstaten wordt ter zake een ruime 'margin of appreciation' gelaten. Van bijzonder belang is in dit verband het Biogeneeskundeverdrag, dat een nadere invulling van het EVRM geeft ten aanzien van biomedische onderwerpen. In het Aanvullend protocol dat betrekking heeft op orgaandonatie $^{14}$ stelt artikel 17 dat organen alleen mogen worden verwijderd als 'consent or authorisation required by law has been obtained'. Die laatste woorden laten ondubbelzinnig ruimte

13 Kamerstukken I 2017/18, 33506, L, p. 15.

14 Additional Protocol to the Convention on Human Rights an Biomedicine concerning Transplantation of Organs and Tissues of Human Origin. 
voor een (wettelijk vastgelegd) opt-outsysteem. Dat blijkt overigens ook uit de Aanbeveling van de Raad van Europa inzake registers voor orgaandonatie: ${ }^{15}$ landen met een wettelijk systeem waarin toestemming wordt verondersteld tenzij bezwaar is aangetekend, moeten zorgen dat burgers hun beslissing op effectieve wijze kunnen vastleggen; een nationale registratie kan daartoe een geschikt middel zijn.

Ten slotte laat ook het EU-recht expliciet ruimte voor een opt-outsysteem. Volgens de Richtlijn inzake kwaliteits- en veiligheidsnormen voor te transplanteren organen mogen menselijke organen slechts worden verkregen nadat is voldaan aan alle nationale voorschriften inzake toestemming of het ontbreken van bezwaar, aldus artikel $14 .{ }^{16}$ Het is aan de lidstaten of zij hierbij voor een opt-in- of een opt-outsysteem kiezen.

Een volgende vraag is of het nieuwe beslissysteem in overeenstemming is met artikel 11 Grondwet. ${ }^{17}$ Dat houdt het recht in te worden gevrijwaard van inbreuken op het lichaam door anderen en zelf over het lichaam te beschikken. Vaststaat dat postmortale orgaanverwijdering ook onder het bereik van dat artikel valt: het betreffende grondrecht eindigt niet op het moment van iemands overlijden, maar blijft ook daarna in beginsel voortbestaan. Dat houdt in dat ook een inbreuk op het lichaam van een overledene een wettelijke grondslag vereist. ${ }^{18}$ Formeel is daarin voorzien in de WOD, en de wetswijziging inzake het ADRsysteem maakt dat niet anders.

Is dat ook inhoudelijk het geval, dat wil zeggen als men de wetswijziging toetst aan criteria van subsidiariteit en proportionaliteit? Interessant is dat reeds bij totstandkoming van de WOD de optie van een geen-bezwaarsysteem aan de orde is geweest, samen met de vraag of de Grondwet daartoe ruimte zou laten. Die vraag werd bevestigend beantwoord. Gezien het zwaarwegende belang van het vergroten van de beschikbaarheid van organen, sluit artikel 11 Grondwet de mogelijkheid van een andere keuze (zoals een geen-bezwaarsysteem) niet uit, aldus destijds de regering. ${ }^{19}$

In zijn advies bij het initiatiefwetsvoorstel is de Raad van State uitvoerig op de kwestie ingegaan. ${ }^{20}$ Ook zijn conclusie is dat het voorgestelde ADR-systeem niet op voorhand in strijd is met artikel 11 Grondwet, maar volgens de Raad behoefde het voorstel in termen van proportionaliteit en subsidiariteit nog wel nadere motivering in de toelichtende stukken.

Mijns inziens is het nieuwe systeem ook inhoudelijk gezien toereikend te rechtvaardigen.

- In de eerste plaats moet men niet uit het oog verliezen dat de beschikking over het eigen lichaam ook onder de WOD maar beperkt gestalte krijgt. In de huidige praktijk is immers ondanks het officieel geldende 'volledig beslissysteem' vooral van beslissen

15 Council of Europe, Recommendation (2003)12 of the Council of Ministers on organ donor registers.

16 Richtlijn 2010/45/EU inzake kwaliteits- en veiligheidsnormen voor menselijke organen bestemd voor transplantatie, PbEU 2010, L 207/14.

17 Zie over die vraag onder meer J.J.C. Dute, 'Het initiatiefvoorstel over orgaandonatie is in strijd met art. 11 Grondwet', TvCR 2017, p. 128-132; A.C. Hendriks, 'Initiatiefwetsvoorstel over orgaandonatie doet grondrechten geen geweld aan', TvCR 2017, p. 133-136; M. Buijsen, 'Actieve donorregistratie en de rechten van de mens', ZIP 2017, nr. 1.

18 Handelingen II $1978 / 79,15463,2$ p. 5.

19 Kamerstukken II 1992/93, 22358, 5, p. 27.

20 Kamerstukken II 2013/14, 33506, 4, p. 9-20. 
door nabestaanden sprake. Ook anderszins kent de WOD trouwens inbreuken op de lichamelijke integriteit, zelfs bij leven. Ik doel op de regeling van de voorbereidende handelingen voor orgaanverwijdering in artikel 22 WOD die ingrepen toelaat bij personen van wie niet vaststaat dat zij überhaupt donor zullen zijn, zelfs al voor hun overlijden. Op dit laatste punt kom ik hieronder nog terug.

- In de tweede plaats is in het nieuwe systeem zonder meer sprake van 'nudging' (het stimuleren van mensen een bepaalde kant op te gaan zonder opleggen van sancties). Doorslaggevend is echter hoeveel keuzevrijheid behouden blijft. ${ }^{21}$ Die hoeft volgens Den Hartogh in het nieuwe systeem niet minder te zijn dan in het oude, zolang men maar even gemakkelijk van de 'default'-situatie kan afwijken en van overheidswege ervoor gezorgd wordt dat men weet welke keuzemogelijkheden men heeft, hoe men geregistreerd staat, en hoe men die registratie kan wijzigen.

- Ten derde is terecht opgemerkt dat bij de beoordeling van de vraag of een ADR-systeem grondwetsconform is alle betrokken belangen zorgvuldig moeten worden meegewogen, ook de belangen van orgaan behoevende patiënten. Dat geldt temeer nu dat belang ook grondwettelijk beschermd wordt door het sociale grondrecht op gezondheidszorg (art. 22 Grondwet), dat ziet op toegankelijkheid en beschikbaarheid van adequate gezondheidszorg. ${ }^{22}$ Waar grondrechten met elkaar botsen is een belangenafweging mogelijk, waarbij het ene grondrecht voorrang krijgt boven het andere, mits men blijft binnen de beperkingsmogelijkheden van laatstgenoemd grondrecht. Dat is bij de wetswijziging ter introductie van het ADR-systeem het geval.

- Ervan uitgaande dat er meer postmortale organen nodig zijn, is een vierde punt of dat ook niet langs andere weg bereikt kan worden. Het gaat dan om factoren die naar de ervaring leert van invloed zijn op het beschikbaar komen van organen, zoals met name goede voorlichting aan burgers, adequate scholing van artsen en verpleegkundigen, verbetering van de noodzakelijke organisatie en procedures in ziekenhuizen, en een adequate benadering van nabestaanden. In ons land is daar echter al heel veel aan gedaan. Uit de derde evaluatie van de WOD (2006) bleek dat na een aantal maatregelen op dat gebied het aantal donoren groeide. Het tekort aan organen bleef echter zodanig dat de mogelijkheid van een systeemwijziging actueel bleef. ${ }^{23}$ Ook daarna zijn dergelijke inspanningen voortgezet, conform het eerder genoemde Masterplan Orgaandonatie (2008) en het EU Action Plan on Organ Donation and Transplantation (2009). Uit een vergelijkende studie van het NIVEL over de implementatie van dat laatste plan blijkt dat in Nederland ten aanzien van alle daarin genoemde actiepunten maatregelen zijn genomen, en dat ons land bovendien ten aanzien van een aantal punten vooroploopt, Europees gezien. ${ }^{24}$ Aan mogelijke alternatieven is dus veel aandacht besteed, maar dat heeft de kwestie van het (te) beperkte aantal registraties niet opgelost. ${ }^{25}$

21 G. den Hartogh, o.c., 2017, zie noot 11.

22 M. Buijsen 2017, zie noot 17; zie ook idem, 'Actieve donorregistratie: mogelijk conflict tussen 2 gelijkwaardige mensenrechten; individuele zelfbeschikking versus eerbied voor de menselijke waardigheid', NTvG 2017; 161; D1418.

23 Kamerstukken II 2007/08, 28140, 43.

24 NIVEL, 'Study on the set-up of organ donation and transplantation in the EU Member States, uptake and impact of the EU Action Plan on Organ Donation an Transplantation' (209-2015).

25 Zie ook Kamerstukken I 2016/17, 33506, G, p. 16 en L, p. 31-33. 
- Ten slotte: mag van een ADR-systeem inderdaad een hoger aanbod aan postmortale organen verwacht worden? Lange tijd heeft in ons land de mening geprevaleerd (in een aantal onderzoeken en in het beleid) dat dat niet het geval was of althans onzeker was. In de internationale literatuur werd ook toen al vaker geoordeeld dat - zonder aan het belang van andere factoren af te doen - er wel degelijk een verband was tussen beslissysteem en donoraantallen. ${ }^{26}$ Ook nu is van absolute zekerheid geen sprake, maar de laatste jaren zijn wel nieuwe internationale onderzoeksresultaten verschenen die de opvatting steunen dat de te verwachten 'opbrengst' van een opt-outsysteem per saldo groter is dan dat van een opt-insysteem. ${ }^{27}$ Ook in de meeste Europese landen is men kennelijk die mening toegedaan, gelet op de keuze voor een geen-bezwaarsysteem (waar Europeesrechtelijk zoals aangegeven ook alle ruimte voor is). Dit alles in aanmerking nemend meen ik dat de (initiatief)wetgever er in redelijkheid van uit mocht gaan dat de aanpassing van het beslissysteem (meer in het bijzonder het vergroten van het aantal registraties) zou leiden tot een groter aanbod aan organen. ${ }^{28}$

Met de keuze voor een ADR-systeem kan men het eens of oneens zijn. Uiteindelijk gaat het daarbij om een politieke beslissing. Als het echter aankomt op de juridische vraag of grond- en mensenrechten die keuze toelaten, dan luidt het antwoord naar mijn oordeel bevestigend.

\subsection{De positie van nabestaanden}

Bij de totstandkoming van de WOD is de rol van de nabestaanden uiteraard aan de orde geweest. Dat was begrijpelijk, want die rol is aanzienlijk: als de wil van de overledene niet uit het register kenbaar is, is hun opvatting doorslaggevend (en dat is nog steeds het geval zolang de wetswijziging nog niet is ingevoerd). Uit de parlementaire stukken van toen blijkt dat die keuze mede is ingegeven door respect voor het belang dat zij hebben bij een nauwe betrokkenheid bij de beslissing over het lichaam van de overledene. Een andere overweging was dat zij op de hoogte kunnen zijn van de wens van de overledene, ook als die niet geregistreerd is. ${ }^{29}$ In de literatuur wordt met name gewezen op de bijzondere emo-

26 Zie voor een beknopt overzicht Kamerstukken II 2013/14, 33506, 6, p. 17-18. Verwezen wordt met name naar Rithalia et al., 'Impact of presumed consent for organ donation on donation rates: a systematic review', BMJ, mei 2009, waarin de resultaten van vier als degelijk bestempelde onderzoeken worden vergeleken. In al deze vier studies bleek - gecorrigeerd voor overige factoren - presumed consent een positieve impact te hebben op het aantal orgaandonaties.

27 Bij de schriftelijke behandeling in de Eerste Kamer (Kamerstukken I 2016/17, 33506, G, p. 21) wordt verwezen naar de meer recente en uitgebreide studie van L. Shepherd e.a., 'An international comparison of deceased and living organ donation/transplant rates in opt-in and opt-out systems: a panel study', BMC Medicine 2014, 12:131, die aantoont dat landen met een opt-outsysteem meer postmortale organen hebben dan landen met een opt-insysteem.

28 Dat lijkt weersproken te worden door het feit dat na aanname van het voorstel in de Tweede Kamer vooral het aantal nee-registraties sterk toenam. Dat kan echter goed komen omdat juist mensen die geen donor willen worden zich geroepen voelen hun keuze voor alle zekerheid te registreren; het doet niet af aan de verwachting dat na invoering van het ADR-systeem het totaal aantal registraties, en daarmee ook het aantal ja-registraties, aanzienlijk zal toenemen (Kamerstukken I 2016/17, 33506, G, p. 19).

29 Kamerstukken II 1991/92, 22358, 3. par. 5.1. G. den Hartogh, 'Repliek', NJB 2018 nr. 7, wijst er verder nog terecht op dat tot aan vaststelling van de Wet orgaandonatie werd aangesloten bij de wettelijke regeling van de sectie waarin nabestaanden ook een prominente positie hadden. 
tionele betrokkenheid van nabestaanden. Volgens Sijmons heeft de wetgever van de WOD gewild dat de nabestaanden hun gevoelens de doorslag konden laten geven; het lichaam behoort op zo'n moment in zekere zin de familie toe. ${ }^{30}$ Aan de samenleving (en de wetgever) past piëteit voor die gevoelens.

Zoals eerder aangegeven wordt de rol van de nabestaanden in de gewijzigde WOD behoorlijk ingeperkt: zij moeten volgens artikel 20 lid 5 'aannemelijk maken' dat de registratie dat hun dierbare heeft toegestemd of geen bezwaar heeft, niet overeenkomt met diens wens. Alleen in dat geval 'geldt de informatie van de nabestaanden'. Op nabestaanden wordt daarmee niet alleen een bepaalde bewijslast gelegd (des te meer als sprake is van een expliciete ja-registratie van de overledene ${ }^{31}$ ), hun functie wordt ook versmald tot die van informatiebron. Hun bijzondere emotionele betrokkenheid speelt geen zelfstandige rol meer.

De Eerste Kamer heeft daarmee geen genoegen genomen. Dat heeft uiteindelijk geresulteerd in een brief van initiatiefneemster aan die Kamer, ${ }^{32}$ waarin naast de mogelijkheid dat nabestaanden 'aannemelijk maken' dat de geregistreerde wens niet klopt, ook ruimte wordt geboden om van orgaanverwijdering af te zien als de nabestaanden 'ernstige bezwaren' hebben. ${ }^{33}$ Met dat laatste wordt recht gedaan aan de staande praktijk, dat artsen ook bij een geregistreerde toestemming verzet van nabestaanden zullen respecteren als die laatsten ernstige emotionele problemen hebben met het feit dat het lichaam van hun dierbare wordt aangetast. In de brief wordt echter aangegeven dat het niet goed mogelijk is dat laatste punt wettelijk te regelen; de initiatiefneemster beroept zich daarbij op eenzelfde opvatting van de regering bij de totstandkoming van de WOD. Wel vindt zij het van belang dat de beoogde rol van nabestaanden en de wijze waarop zij in dat verband te benaderen zijn, worden opgenomen in een veldnorm of protocol zoals bedoeld in artikel 23 lid 1 WOD. De Eerste Kamer heeft in het verlengde daarvan een motie aangenomen, waarin de regering wordt verzocht een landelijk uniforme wijze van handelen jegens nabestaanden, inclusief het respecteren van eventuele ernstige bezwaren, te laten vastleggen in een kwaliteitsstandaard voor de transplantatiezorg en het gebruik van die standaard te verankeren in de in artikel 23 lid 3 WOD genoemde AMvB. ${ }^{34}$

Het komt erop neer dat ook na de wetswijziging in ons land bij onoverkomelijke bezwaren van nabestaanden geen orgaanverwijdering zal plaatsvinden, waarmee in feite de bestaande praktijk in dezen wordt voortgezet. Niet goed te begrijpen is, waarom dat ook niet in de wet kon worden vastgelegd. Men zou daarin toch best kunnen opnemen dat (ook) bij ‘ernstige bezwaren' van nabestaanden orgaanuitname geen doorgang kan vinden. Onze wetgeving kent wel meer van die open normen. Nu moeten we het doen met het toe-

30 J.G. Sijmons 2013, zie noot 3. Die bijzondere positie blijkt overigens ook uit de bevoegdheden van de nabestaanden op grond van de Wet op de lijkbezorging. Zie in gelijke zin over de positie van nabestaanden: M.C. Ploem en J.C.J. Dute,' Wetenschappelijk onderzoek na overlijden: goed geregeld?', TvGR 2016, p. 498-512.

31 Aldus Kamerstukken I 2017/18, 33506, L, p. 24.

32 Kamerstukken I 2017/18, 33506, P.

33 Bovendien wordt ten aanzien van het 'aannemelijk maken' gesteld dat het daarbij niet om 'bewijzen' gaat, maar om 'het tegenover de arts uiteenzetten dat de geregistreerde wil van de geliefde niet (meer) zijn werkelijke wil representeert'.

34 Motie van het lid Nooren, Kamerstukken I 2017/18, 33506, S. 
zeggingen aan Eerste Kamer dat de wet op een andere manier zal worden toegepast dat de tekst suggereert. Dat is geen novum, ${ }^{35}$ maar daarom niet minder jammer.

\subsection{Wilsonbekwaamheid}

Een minder opvallend, maar in de praktijk wel relevant onderdeel van de wetswijziging betreft de positie van wilsonbekwamen, met name meerderjarigen. Aandacht daarvoor is vanuit gezondheidsrechtelijk oogpunt ook gewettigd omdat de nieuwe regels nogal opmerkelijk zijn.

Voorafgaand aan de wetswijziging bepaalde de WOD in artikel 9 lid 1 dat alleen meerderjarigen (en minderjarigen van twaalf jaar of ouder) die in staat zijn tot een redelijke waardering van hun belangen ter zake, toestemming kunnen geven voor verwijdering van hun organen post mortem. Daaruit volgde impliciet, dat wilsonbekwamen in principe zijn uitgesloten van orgaandonatie. ${ }^{36}$ Dat is na de wetswijziging niet langer het geval. Aan artikel 9 lid 1 WOD is nu de zin toegevoegd dat de wettelijk vertegenwoordiger van wilsonbekwame meerderjarigen namens hen toestemming kan geven voor of bezwaar kan maken tegen het na hun overlijden verwijderen van organen.

Bij die toevoeging is het niet gebleven. De wet voorziet nu ook in de situatie dat een wilsonbekwaam iemand wordt aangeschreven om zich te laten registreren en daarop niet adequaat kan reageren. Volgens het nieuwe artikel 10a lid 4 wordt dan de geregistreerde toestemming $^{37}$ vervangen door de registratie dat de beslissing wordt overgelaten aan een bepaalde persoon, zijnde de wettelijk vertegenwoordiger van betrokkene. Verder wordt in het nieuwe artikel 11 lid 2 bepaald dat als van een wilsonbekwame meerderjarige toestemming of geen bezwaar is geregistreerd, na het vaststellen van de dood die toestemming of dit geen bezwaar bevestigd wordt of teniet wordt gedaan door zijn wettelijk vertegenwoordiger. Het sluitstuk is te vinden in artikel 21 lid 2 nieuw, dat bepaalt dat de in artikel 23 bedoelde functionaris (de coördinator orgaandonatie in een ziekenhuis) voordat organen worden uitgenomen zich ervan moet vergewissen dat de overledene ten tijde van het verlenen van toestemming dan wel van de registratie als bedoeld in artikel 10a (de registratie volgend op de aanschrijvingen) wilsbekwaam was.

Met bovenstaand regime heeft men kennelijk getracht een sluitend geheel van regels op te stellen om in het kader van het nieuwe ADR-systeem zo goed mogelijk met wilsonbekwaamheid om te gaan en tegelijk te voorzien in de lacune in de 'oude' WOD. Dat is te prijzen, maar er zijn wel een aantal kritische kanttekeningen te plaatsen.

Is de strekking van het geheel duidelijk (als wilsonbekwaamheid aannemelijk is, is de beslissing aan de wettelijk vertegenwoordiger), op onderdelen rijzen verschillende vragen. Een punt is bijvoorbeeld hoe de betreffende bepalingen zich precies tot elkaar verhouden en in elkaar grijpen. Kennelijk betreft artikel 10a lid 4 de situatie dat bij of op enig moment na het registratieproces duidelijk wordt dat sprake is van een wilsonbekwame, terwijl arti-

Vgl. bijv. de parlementaire gang van zaken rond de inzagebevoegdheid van de inspectie; zie J.H. Hubben e.a., 'Naar een samenhangend kader voor het gebruik van de bevoegdheid tot inzage van patiëntendossiers door de IGZ', TvGR 2015, p. 20-28.

36 In principe, want in bepaalde omstandigheden kunnen nabestaanden namens hen beslissen (art. 11 lid 2).

37 De wet gebruikt hier het woord 'toestemming'. Dit lijkt een vergissing of in elk geval onvolledig, immers als betrokkene wordt aangeschreven en niet reageert wordt hij/zij geregistreerd als een persoon die geen bezwaar heeft; ik neem derhalve aan dat bedoeld is: 'toestemming of geen bezwaar'. 
kel 11 lid 2 ziet op de omstandigheid dat pas na overlijden duidelijk wordt dat de toestemming of geen-bezwaarregistratie een wilsonbekwaam persoon betreft. ${ }^{38}$ Een andere vraag is wat geldt als iemand later in het leven wilsonbekwaam wordt, maar eerder een beslissing over orgaandonatie heeft kunnen nemen. Volgens de toelichtende stukken moet die beslissing worden opgevolgd, ${ }^{39}$ maar volgens artikel 11 lid 2 geeft dan de stem van de vertegenwoordiger de doorslag. En wie zijn eigenlijk 'wettelijk vertegenwoordiger'? Volgens de Kamerstukken is dat een curator of mentor. ${ }^{40}$ Die zullen er echter vaak niet zijn; volgens artikel 11 lid 2 zal dan uiteindelijk (na overlijden) terug worden gevallen op de nabestaanden.

Vanuit gezondheidsrechtelijk (en familierechtelijk) oogpunt is vooral opmerkelijk dat de bevoegdheid van wettelijk vertegenwoordigers wordt uitgebreid buiten de daarvoor geaccepteerde grenzen, en wel in tweeërlei opzicht. Enerzijds krijgen mentor en curator de bevoegdheid te beslissen over orgaandonatie, terwijl algemeen aanvaard is dat vertegenwoordiging bij hoogstpersoonlijke beslissingen niet mogelijk is; anderzijds is in het BW bepaald dat mentorschap en curatele eindigen bij het overlijden van de cliënt. ${ }^{41} \mathrm{Als}$ mentor en curator mogen beslissen over een hoogstpersoonlijke zaak als orgaandonatie, en dan ook nog na overlijden, waar ligt dan nog de grens aan hun bevoegdheden, aldus terecht Blankman. De initiatiefneemster ziet hier echter geen probleem: wettelijke vertegenwoordiging heeft betrekking op aangelegenheden betreffende verzorging, verpleging, behandeling en begeleiding. Daaronder vallen volgens haar ook beslissingen inzake donatie, ook als die na overlijden van de betrokkene moeten worden genomen. ${ }^{42}$

Een laatste kwestie betreft het cruciale, in de praktijk vaak weerbarstige punt van vaststelling van wilsonbekwaamheid. Die kwestie spitst zich vooral toe op de in artikel 21 lid 2 opgenomen vergewisplicht, inhoudend dat men zich er in het ziekenhuis van moet vergewissen dat de overledene 'ten tijde van het verlenen van toestemming dan wel van de registratie als bedoeld in artikel 10a wilsbekwaam was'. Hoe moet men zich dit in de praktijk voorstellen? Bij de behandeling in de Eerste Kamer is initiatiefneemster daarover flink aan de tand gevoeld. De vereniging van intensive care artsen (NVIC) is haar echter te hulp geschoten. Deze schrijft in een brief aan de Kamer: 'Het moge duidelijk zijn dat een onbekende patiënt nooit kan doneren. De vergewisplicht zoals die in het initiatiefwetsvoorstel is opgenomen, wordt (...) derhalve niet als verzwaring van onze werkzaamheden gezien, aangezien dit al conform de huidige praktijk is. ${ }^{43}$ Dat moge zo zijn, het is ook duidelijk dat men in het ziekenhuis als het erop aankomt slechts beperkte tijd en mogelijkheden heeft om vast te stellen of de betrokkene toen hij toestemming gaf wel of niet wilsbekwaam was. Ook de initiatiefneemster moest dat toegeven. Het ligt volgens haar in de rede dat de arts aan zijn vergewisplicht in eerste instantie uitvoering geeft door het raadplegen van de huisarts en andere medici; daarnaast kunnen ook nabestaanden informatie geven. Er is volgens

38 In die zin ook Kamerstukken II 2013/14, 33506, 6, p. 16.

39 Kamerstukken I 2016/17, 33506, G, p. 44.

40 Idem, p. 45.

41 Zie hierover met name K. Blankman, 'Vertegenwoordigers en de nieuwe donorwet', Jnl GGZ en Recht 2018, nr. 2.

42 Kamerstukken I 2016/17, 33506, G. p. 45.

43 Kamerstukken I 2017/18, 33506, L, p. 29. 
haar hoe dan ook slechts sprake van een inspanningsverplichting die, zoals alle verplichtingen van dien aard, haar grenzen heeft. ${ }^{44}$

\subsection{Voorbereidende handelingen}

Voordat organen na overlijden worden uitgenomen moeten een aantal voorbereidende handelingen worden getroffen. Aandacht voor dat onderwerp is gewettigd, omdat de wet ook op dat punt is aangepast.

De WOD zoals die oorspronkelijk luidde, leverde voor de praktijk twee problemen op die allebei betrekking hadden op de situatie dat in het ziekenhuis (bijvoorbeeld na een verkeersongeluk) een ten dode opgeschreven patiënt wordt binnengebracht van wie geen wilsverklaring bekend is. Wil die patiënt als donor kunnen fungeren, dan moeten medisch gezien al voor diens overlijden een aantal handelingen worden verricht (zoals beademing en bloeddrukstabilisatie, eventuele bloedtransfusies). Dat is echter niet goed mogelijk als niet eerst de nabestaanden is gevraagd toestemming te geven voor donatie. Volgens de wet (art. 11 lid 1), kan die toestemming echter pas na het overlijden worden verstrekt. Het tweede probleem betreft het feit dat de genoemde maatregelen en maatregelen om de organen geschikt te houden voor implantatie volgens artikel 22 sowieso pas na het intreden van de dood mochten worden toegepast. ${ }^{45}$

Om aan die problemen tegemoet te komen is in 2010 het wetsvoorstel Wijziging van de Wet op de orgaandonatie in verband met nieuwe medisch-technische ontwikkelingen ingediend. ${ }^{46}$ Daarin blijft de regel in stand dat nabestaanden pas na het overlijden plaatsvervangende toestemming kunnen geven voor orgaandonatie, maar artikel 22 wordt zodanig verruimd dat de spanning tussen wet en praktijk wordt opgeheven. Als geen wilsverklaring bekend is mogen namelijk reeds voor het vaststellen van de dood voorbereidingen worden getroffen, mits vaststaat dat de betrokkene binnen afzienbare tijd zal overlijden. Die voorbereidingen mogen niet uitgesteld kunnen worden tot na overlijden, en niet strijdig zijn met de geneeskundige behandeling van de betrokkene. Verder moet de informatie die in een dergelijke situatie verstrekt moet worden aan de nabestaanden over de mogelijkheid van orgaandonatie, nog niet hebben geleid tot bezwaren van hun kant. Afhankelijk van de situatie (wordt de patiënt reeds wel of niet beademd) kunnen die voor het overlijden toe te passen maatregelen niet alleen implantatie-voorbereidend onderzoek inhouden, maar ook (voorzetting van de) kunstmatige beademing, kunstmatig in stand houden van de bloedsomloop, en andere maatregelen noodzakelijk om organen geschikt te houden voor implantatie. ${ }^{47}$ Volgens de regering rechtvaardigt het belang van orgaanbehoevenden bij het beschikbaar komen van meer geschikte organen dat bij leven, doch kort voor overlijden, voorbereidingen voor orgaandonatie kunnen worden getroffen zonder de toestemming daarvoor van de betrokkene zelf of van zijn naasten, ook al wordt daarmee in feite

45 G. van Dijk, E. Kompanje, 'Bijna altijd in overtreding; Wet op de orgaandonatie sluit niet aan bij de praktijk', Med. Contact 2007, p. 1802-1804.

46 Kamerstukken II 2010/11, 32711, 1-3.

47 Bij die laatste categorie maatregelen kan bijvoorbeeld gedacht worden aan het toedienen van bloeddrukregulerende medicatie, het aansluiten van infusen voor vochtregulatie en het toedienen van medicatie om polyurie (vermeerdering urinelozing) tegen te gaan; Kamerstukken II 2011/12, 32711, 6 , p. 3. 
een extra geen-bezwaar-element in de wet geïntroduceerd (bedoeld wordt: naast de reeds bestaande mogelijkheid van preserverende handelingen bij reeds overleden patiënten). ${ }^{48}$

Dat neemt niet weg dat de Raad van State in zijn advies bij het betreffende wetsvoorstel moeite had om een en ander te rijmen met artikel 11 Grondwet (bescherming van de lichamelijke integriteit, in beginsel ook na overlijden), met name vanwege de mogelijkheid om nog voordat nabestaanden hebben beslist over orgaandonatie, met voorbereidende en preserverende handelingen te starten. In feite wordt dan verondersteld dat er geen bezwaar van de betrokkene is tegen dergelijke maatregelen zolang de nabestaanden nog niet in negatieve zin hebben beslist, aldus de Raad. Volgens de Raad zou een dergelijke consequentie van het niet laten registreren van toestemming of bezwaar in elk geval uitdrukkelijk via voorlichting gecommuniceerd moeten worden en ook op het donorformulier geëxpliciteerd moeten worden, zodat aan de bevolking kenbaar is wat de consequenties van niet registreren kunnen zijn. ${ }^{49}$ In de Eerste Kamer is vervolgens aan dit wetsvoorstel nauwelijks nog aandacht besteed (het is zonder voorbereidende behandeling, beraadslaging en hoofdelijke stemming aangenomen). ${ }^{50}$ Wellicht heeft de suggestie in de titel dat het slechts om medisch-technische kwesties gaat, daarbij een rol gespeeld.

$\mathrm{Na}$ de wetswijziging en de introductie van een ADR-systeem geldt de mogelijkheid van het uitvoeren van voorbereidende handelingen voor iedereen van wie toestemming of geen bezwaar geregistreerd staat (dat laatste is zoals aangegeven het geval als men na herhaald aanschrijven niet gereageerd heeft), en verder ook voor degenen van wie om een of andere reden helemaal geen registratie in het donorregister aanwezig is, aldus het nu opnieuw aangepaste artikel 22.

De geringe aandacht die de afgelopen jaren en ook weer bij de recente wetsherziening aan deze tamelijk vérgaande ingrepen in de integriteit van het lichaam bij leven is geschonken, staat nogal in contrast met alle commotie rond de wijziging van het beslissysteem. Vandaar dat ik op dit onderwerp ben ingegaan, ook al houdt de recente wetswijziging die ik in dit artikel bespreek op dit punt formeel niet meer in dan aanpassing van artikel 22 aan het nieuwe beslissysteem. Maar dat maakt de betreffende bepalingen niet minder ingrijpend. Terecht merkt Kompanje op dat donatie meer behelst dan het louter uitnemen van organen. 'Het betekent immers ook het instemmen met de gehele donorbehandeling op de intensive care met alle consequenties van dien voor het verloop van de stervensfase en met name de manier van overlijden. ${ }^{51}$ De vraag of mensen zich dat wel realiseren is onder het nieuwe beslissysteem zeker niet minder relevant.

\section{Slotopmerkingen}

In deze bijdrage heb ik met name het nieuwe beslissysteem voor postmortale orgaandonatie besproken, inclusief de rol van de nabestaanden daarbij, en wel enerzijds in het licht van de ontwikkelingsgang van het initiatiefwetsvoorstel ter zake, anderzijds in de bredere con-

48 Kamerstukken II 2010/11, 32711, 4, p. 8-9.

49 Kamerstukken II 2010/11, 32711, 4, p. 6-7.

50 Wet van 25 april 2013, Stb. 2013, 200.

51 E. Kompanje 2017, zie noot 12. 
text van de WOD. De vraag is nu eerst en vooral wat dat nieuwe systeem zal gaan opleveren, en of het zijn beloften zal gaan waarmaken. Daar is tijd voor nodig.

Artikel 35 WOD voorzag reeds in evaluatie van de wet binnen drie jaar en vervolgens na vijf en na zeven jaar na inwerkingtreding. Dat artikel is bij de wetswijziging in stand gebleven en ziet - aldus de initiatiefneemster - ook toe op de evaluatie van de gewijzigde wet. $^{52}$ Dat betekent dat we (bij invoering medio 2020) in 2023 een eerste 'verslag over de effecten van de doeltreffendheid van de wet' tegemoet kunnen zien. We moeten dus nog even wachten, maar de registratie- en donatiestatistieken over de komende jaren zullen intussen ongetwijfeld al een indicatie gaan geven. 